\title{
Hepatitis B Management in the Pregnant Patient: An Update
}

\author{
Walid S. Ayoub*1,2 and Erica Cohen ${ }^{2}$ \\ ${ }^{1}$ Department of Gastroenterology and Hepatology, Comprehensive Transplant Center, Cedars Sinai Medical Center, \\ Los Angeles, CA, USA; ${ }^{2}$ Department of Gastroenterology and Hepatology, Cedars Sinai Medical Center, Los Angeles, CA, USA
}

\begin{abstract}
Chronic hepatitis B is a worldwide disease, with significant burden on health care systems. While universal vaccination programs have led to an overall decrease in incidence of transmission of hepatitis $B$, unfortunately, there remain large areas in the world where vaccination against hepatitis $B$ is not practiced. In addition, vertical transmission of hepatitis $B$ persists as a major concern. Hepatitis B treatment of the pregnant patient requires a thorough assessment of disease activity and close monitoring for flares, regardless of initiation of antiviral therapy. We discuss, in this article, the current and emergent strategies which aim to reduce the rate of transmission of hepatitis B from the pregnant mother to the infant and we review the updated guidelines regarding management of liver disease in pregnant women with hepatitis B.

(c) 2016 The Second Affiliated Hospital of Chongqing Medical University. Published by XIA \& HE Publishing Inc. All rights reserved.
\end{abstract}

\section{Introduction}

A staggering 2 billion people are infected with the hepatitis $B$ virus (HBV) worldwide. According to the latest global estimates, 350-400 million of those individuals become chronically infected with the virus. ${ }^{1}$ The burden of chronic hepatitis $B$ in the United States alone is estimated to range from 550,000 to 2 million, ${ }^{2}$ of which up to $80 \%$ of the patients are foreignborn. ${ }^{3}$ Chronic hepatitis B infection is the leading cause of liver disease worldwide, with $20 \%$ of those patients at risk for further complications including hepatocellular carcinoma and cirrhosis. $^{4}$

Although there is a safe and effective vaccine, 50 million new cases are diagnosed annually worldwide. ${ }^{5}$ The majority of new diagnoses, however, are classified as mother-to-child transmission (MTCT), especially in regions with high prevalence of the disease. ${ }^{6}$ In the United States, HBV is usually

Keywords: Hepatitis B; Pregnancy; Liver; Vertical Transmission.

Abbreviations: HBV, hepatitis B virus; MTCT, mother-to-child transmission; AASLD, American Association for the Study of Liver Disease; ACOG, American College of Obstetrics and Gynecology; HBIG, HBV immune globulin; ALT, alanine aminotransferase; $\mathrm{HBeAg}$, hepatitis $\mathrm{B}$ e antigen; $\mathrm{HBcAg}$, hepatitis $\mathrm{B}$ core antigen; HBsAg, hepatitis B surface antigen; DNA, deoxyribonucleic acid; ACG, American College of Gastroenterology.

Received: 01 April 2016; Revised: 17 August 2016; Accepted: 04 September 2016

DOI: $10.14218 /$ JCTH.2016.00014

*Correspondence to: Walid S. Ayoub, Department of Gastroenterology and Hepatology, Comprehensive Transplant Center, Cedars Sinai Medical Center, 8900 Beverly Blvd, Los Angeles, CA 90048, USA. Tel: +1-310-423-6000, Fax: +1-310-423-2356, E-mail: Walid.Ayoub@cshs.org transmitted through sexual contact or intravenous drug use, ${ }^{7}$ but more than 25,000 infants annually are at risk for vertical transmission. ${ }^{8}$ Barriers to eradication of HBV transmission to offspring include under-utilization of immunoprophylaxis with hepatitis $B$ vaccination and HBV immune globulin (HBIG), as well as failure of immunoprophylaxis. Emerging data has identified an association between high maternal levels of HBV viral load and increased risk of MTCT. ${ }^{9,10}$ The current guidelines recommend treatment initiation based on disease stage, as determined by HBV viral load, serologic status and degree of liver injury. Therapeutic options include oral nucleos(t)ide analogues and interferon. ${ }^{11}$

Female patients of childbearing age present a unique challenge to clinicians, who must facilitate appropriate counseling to ensure safe treatment of a mother during pregnancy and in the post-partum stage. This review article will first discuss the natural history of HBV infection as it relates to the known mechanisms of MTCT. Second, it will discuss the approach to treatment initiation for women of childbearing age. Lastly, it will discuss the current and emerging strategies aimed at controlling hepatitis $B$ in the pregnant patient in order to reduce vertical transmission to her offspring. In particular, the available evidence behind the recommendations put forth by the American Association for the Study of Liver Disease (AASLD) and the American College of Obstetrics and Gynecology (ACOG) will be reviewed, as well as recommendations from thought-leaders in the field.

\section{Stages of HBV}

The risk for development of chronic HBV infection is inversely related to the age of exposure. Infants exposed to HBV progress to a chronic infection in $90 \%$ of cases, whereas toddlers and young children clear the virus in only $50 \%$ of cases. ${ }^{12}$ Infection in the adult population, however, is associated with only a $5 \%$ rate of progression to chronic disease. In adults, exposure to hepatitis B typically presents with an acute syndrome and viral clearance is more prevalent. One possible mechanism for this age-related phenomenon was prescribed by Publicover and colleagues ${ }^{13}$ based upon their findings from a study using a mouse model of HBV infection. The researchers explained that since CXCL13, a B lymphocyte involved in trafficking and lymphoid development, is expressed in an age-dependent manner in both adult mice and human hepatic macrophages, its expression may be involved in promoting an immune response to control the virus. ${ }^{13}$ Given these findings, pregnant women with chronic $\mathrm{HBV}$ are an important population to target in order to decrease the overall burden of HBV infection worldwide.

Chronic hepatitis B progresses through four phases (Table 1). The variability in the phase duration and the 
Ayoub W.S. et al: Hepatitis management in the pregnant patient

Table 1. Characteristics of the phases of HBV infection

\begin{tabular}{|c|c|c|c|c|c|}
\hline Phase & HBeAg & HBV DNA & ALT & Liver histology & $\begin{array}{l}\text { Indication for } \\
\text { treatment }\end{array}$ \\
\hline Immune-tolerant & Positive & $\begin{array}{l}\text { Elevated: } \\
\text { >200,000 IU/mL }\end{array}$ & Normal & $\begin{array}{l}\text { Minimal inflammation and } \\
\text { fibrosis }\end{array}$ & No \\
\hline $\begin{array}{l}\text { HBeAg-positive } \\
\text { Immune-active }\end{array}$ & Positive & $\geq 20,000 \mathrm{IU} / \mathrm{mL}$ & $\begin{array}{l}\text { Elevated } \\
>2 \times \text { ULN }\end{array}$ & $\begin{array}{l}\text { Moderate to severe } \\
\text { inflammation or fibrosis }\end{array}$ & Yes \\
\hline Inactive $\mathrm{CHB}$ & Negative & $\begin{array}{l}\text { Low or } \\
\text { undetectable }\end{array}$ & Normal & $\begin{array}{l}\text { Minimal inflammation, } \\
\text { variable fibrosis }\end{array}$ & No \\
\hline $\begin{array}{l}\mathrm{HBeAg-negative} \\
\text { reactivation phase }\end{array}$ & Negative & $\begin{array}{l}\text { Elevated: } \\
\geq 2,000 \mathrm{IU} / \mathrm{mL}\end{array}$ & Elevated & $\begin{array}{l}\text { Moderate to severe } \\
\text { inflammation or fibrosis }\end{array}$ & Yes \\
\hline
\end{tabular}

Abbreviations: ALT, alanine aminotransferase; CHB, chronic hepatitis B; HBeAg, hepatitis B e antigen; HBV, hepatitis B virus; ULN, upper limit of normal.

frequency of fluctuation between phases of infection can lead to difficulty in characterizing a patient's disease status. While immune tolerance is the hallmark of the first phase of the disease, the second phase is characterized by immune activity or viral clearance. In the third phase, the host enters into an inactive carrier state, and in the fourth phase the (now chronic) hepatitis $B$ is reactivated.

Patients in the immune-tolerant phase tend be of younger age, and are typically infected in the perinatal period. In this stage, there is little immune response raised against the virus, a very high viral load, normal alanine aminotransferase (ALT) level and little inflammation (as seen on liver biopsy). The viral mechanism leading to the immune-tolerant state is not well understood but may be related to inadequate $T$ cell response. ${ }^{14}$ Fetal infection is thought, in part, to be secondary to trans-placental maternal hepatitis $\mathrm{B}$ e-antigen ( $\mathrm{HBeAg}$ ) induction of T cell intolerance to the HBV core antigen and to $\mathrm{HBeAg}$ in the neonate. ${ }^{15}$ As neonates lack IgM antibodies to the hepatitis $B$ core antigen ( $\mathrm{HBCAg})$, they cannot mount a primary response. ${ }^{16}$

The mark of the beginning of the immune-active phase includes elevated ALT level, HBeAg positivity, fluctuating viral load, and inflammation (as seen on liver biopsy). This stage can continue for weeks or several years. If the immune response is able to clear the HBeAg and develop a corresponding antibody, then the patient has transitioned to the inactive carrier status. If, however, the HBeAg is not cleared, then the patient may develop ongoing liver damage. Initiation of anti-viral therapy is recommended to halt the progression of HBV infection to liver diseases, with the long-term goal of hepatitis B surface antigen (HBsAg) reduction to non-detectable levels or eradication. It is important to note that treatment of HBV with antiviral drugs decreases liver fibrosis, but does not entirely eliminate risk of developing liver cancer. As a result, ongoing hepatocellular carcinoma surveillance is recommended for an indefinite period. ${ }^{5}$

Transition to the inactive carrier phase is characterized by clearance of $\mathrm{HBeAg}$ and development of its respective antibody. During this phase, HBV deoxyribonucleic acid (DNA) levels are low and the ALT level is normal, due to decreased immune activity. The degree of abnormal liver histology depends on the extent of injury that occurred during the immune-active phase. The inactive carrier phase confers a favorable diagnosis in the absence of preceding liver injury. In addition, patients may experience histologic improvement and cessation of disease progression. Close observation is recommended during this stage, even though the patients are considered to be at low-risk of disease progression. Indeed, a recent study, in which 146 inactive carriers were followed for over 2 decades, $29 \%$ presented increases in ALT levels above normal, while a single patient experienced spontaneous reactivation despite the $\mathrm{HBeAg}$-negative state and two patients developed hepatocellular carcinoma. ${ }^{17}$

Although HBsAg clearance is rare in this stage, $0.5 \%$ of those with inactive chronic hepatitis $B$ annually will spontaneously clear HBsAg, thereby classified under a "cure" status. However, these patients are still at risk of liver disease progression, especially if the clearance occurred late in life. The prolonged immune response is thought to permit progression of liver disease. ${ }^{18} \mathrm{~A}$ minority of patients that achieves HBsAg seroclearance will have transiently detected viremia. However, if HBsAg clearance occurs, the patient has lowered risk of liver decompensation and higher chance of survival. These benefits are irrespective of the mode of seroclearance (spontaneous versus medical therapy-induced). ${ }^{19}$

Up to $80 \%$ of patients who achieve spontaneous $\mathrm{HBeAg}$ seroconversion will remain in the inactive phase, while the remaining $20 \%$ spontaneously revert to $\mathrm{HBeAg}$ positivity. Males, individuals infected with genotype $\mathrm{C}$ and individuals over 40 years of age are at highest risk of reverting back to HBeAg positivity. ${ }^{5}$

It is possible for viral reactivation to occur even after years of the virus being in the quiescent state. In this case, as in the inactive carrier state, $\mathrm{HBeAg}$ is notably absent. This is due to a dominant pre-core stop codon that eliminates the wild-type e-antigen. ${ }^{20}$ Patients with this type of infection are at an increased risk of progression of liver disease, compared to those with $\mathrm{HBeAg}$-positive infection. ${ }^{19}$ Differentiating between inactive carriers and chronic active $\mathrm{HBeAg}$-negative patients is difficult. However, HBsAg levels may help delineate the inactive carriers, as they tend to be lower than in chronic active carriers. ${ }^{21}$

\section{Management of women of childbearing age}

The decision to initiate therapy in women of childbearing age must weigh the risk of liver progression, concern for vertical transmission and increased risk of perinatal flares with possible medication side effects and adverse fetal outcomes. Typically, women of childbearing age are not candidates for antiviral therapy owing to early stage of the HBV disease. However, such patients with high viremia may benefit from antiviral therapy when planning to become pregnant since it reduces the risk of perinatal transmission. 
If a woman of childbearing age presents with chronic HBV and is not pregnant, the aim of management is to determine disease severity, as in any other patient. This is accomplished by assessing HBV DNA level and HBeAg status, and by evaluating the presence and extent of liver injury by measuring ALT level and/or investigating liver histology. Most often women of childbearing age do not have active inflammation. Therefore, the AASLD practice guidelines do not recommend initiation of antiviral therapy. ${ }^{5}$ Similarly, guidelines concur that women with chronic HBV who are planning to conceive should not be started on antiviral therapy due to concerns regarding fetal exposure to these drugs in early pregnancy and their effects on organogenesis. However, patients with significant liver injury, including fibrosis and cirrhosis, should be placed on and/or continue the antiviral drug regimen to prevent flares during pregnancy. Pegylated-interferon is the only finite treatment course available for chronic hepatitis $B$ infection. This may be a good option for women who wish to conceive and who are willing to wait 18 months (consisting of 12 months of therapy followed by 6 months to assess the response) prior to conceiving. Among the available therapies, the interferon injection results in a higher percentage of clinical remission and $\mathrm{HBeAg}$ seroconversion than the oral antiviral agents. ${ }^{22}$

Women who have been started on antiviral therapy and then become pregnant require a careful discussion of the risks of antiviral discontinuation against fetal exposure. Patients with underlying cirrhosis are at highest risk of HBV decompensation during the perinatal period. A retrospective review of almost 400 mothers with HBV-related cirrhosis found that $15 \%$ experienced a severe flare while pregnant and demonstrated a $1.8 \%$ risk of maternal mortality and $5.2 \%$ risk of fetal death. ${ }^{23}$ In another case series involving 12 women it was found that viral rebound occurred in 8 of the patients and 6 of the patients experienced a 5 -fold increase in ALT levels after discontinuation of therapy during pregnancy. ${ }^{24}$ All patients subsequently recovered, but these findings underscored the potential consequences of medication cessation in a pregnant patient. As a result, it is recommended that antiviral therapy be continued in a pregnant female with decompensated cirrhosis.

\section{Pregnancy and HBV-related liver disease}

Chronic hepatitis B infection alone does not adversely affect rates of fertility or fetal outcomes. ${ }^{25}$ However, women with decompensated cirrhosis as a result of HBV infection have impaired fertility, due to the associated hormonal imbalances, and are at risk of maternal and perinatal death, gestational hypertension, abruption, preterm birth and fetal growth restriction. ${ }^{26,27}$ On the contrary, pregnancy itself does not directly impact HBV-related liver disease. Although alterations in hormone levels during pregnancy may be involved in acute flares due to changes in viral load and levels of liver enzymes. ${ }^{25}$

\section{Screening the pregnant patient}

The American Congress of Obstetrics and Gynecology recommend that every pregnant patient undergo HBV screening. Levels of HBsAg and surface antibody should be measured at the earliest prenatal visit. ${ }^{28}$ If the testing shows negativity for both, then an HBV vaccination series should be administered to the high-risk individuals. If the HBsAg testing shows positivity, then the clinician should confirm infection with quantitative measurement of HBV DNA at baseline and at week 28, along with $\mathrm{HBeAg}$ status and ALT levels. Individuals who are sexual contacts and household members of the HBsAg-positive pregnant woman should also be screened. The ACOG recommends referral to a specialist immediately if viral load is $>20,000 \mathrm{IU} / \mathrm{mL}$, ALT is $>19 \mathrm{IU} / \mathrm{mL}$ or $\mathrm{HBeAg}$ is positive. ${ }^{28,29}$ If these criteria are not met the referral can be post-partum. If the patient's viral load $>1$ million copies $(200,000 \mathrm{IU} / \mathrm{mL})$, then consideration of antiviral therapy at week 32 is recommended. If the viral load is $<200,000$ $\mathrm{IU} / \mathrm{mL}$, antiviral therapy is not recommended unless the pregnant female has active liver disease. All infants require the HBV vaccination series and HBIG within 12 hours of birth. Delays in obtaining passive-active immunoprophylaxis can also lead to viral transmission to the fetus. Fig. 1 summarizes these recommendations.

\section{Reducing MTCT}

The main goal of antiviral therapy in the pregnant patient is to reduce the rates of vertical transmission. Immunoprophylaxis with HBIG and HBV vaccination immediately after birth that is followed by completion of the vaccination series has been used to prevent MTCT in the setting of HBsAg-positive mothers. Unfortunately, this modality fails to prevent transmission in up to $30 \%$ of children. ${ }^{25}$ Zou et al $l^{30}$ studied a large cohort of 1043 mothers and found a correlation between maternal HBV DNA levels and immunoprophylaxis failure that indicated maternal pre-delivery HBV DNA levels $>6 \log 10$ copies $/ \mathrm{mL}$ are associated with reduced prophylaxis effectiveness. Bai et $\mathrm{al}^{31}$ corroborated this finding by showing that intrauterine transmission may be due to HBV crossing the placental barrier, according to positive HBV staining of placental tissue in mothers with high viral loads. In contrast, postnatal transmission is very rare and not currently a target of prevention.

In the general population, antiviral agents with high barrier to resistance (i.e. tenofovir and entecavir) remain first-line oral therapies (Table 2). Antiviral agents with excellent safety profiles but a lower resistance barrier (i.e. lamivudine and telbivudine) can lead to cross-resistance with other agents. Among the available oral nucleos(t)ide agents, data is available for the use of tenofovir, lamivudine and telbivudine in pregnancy; in contrast, there is limited data regarding the use of entecavir and adefovir in pregnancy and they are not currently recommended in this population.

Based on the available data from the CDC and Registries of HIV-Infected Mothers, there is no significant difference in the rate of adverse outcomes if the HBV drug was initiated in the first trimester compared to later on in pregnancy. ${ }^{32}$ The risk of continuation of a prior antiviral therapy upon becoming pregnant appears low, and is recommended in patients with fibrosis or decompensated liver disease to prevent flares. If there is concern about prolonged fetal exposure in those without advanced disease, therapy can be withheld as long as close follow-up is maintained. All oral nucleos(t)ide agents inhibit HBV DNA polymerases, but also interfere with mitochondrial DNA replication, which can lead to lactic acidosis. ${ }^{19}$ Little is known about the specific effects of mitochondrial toxicity in the developing fetus during organogenesis of the first trimester. Shared decision-making and ongoing discussion with patients regarding the risk to the fetus versus the risk related to the mother's liver decompensation are vital for effective management of this population. 
Ayoub W.S. et al: Hepatitis management in the pregnant patient

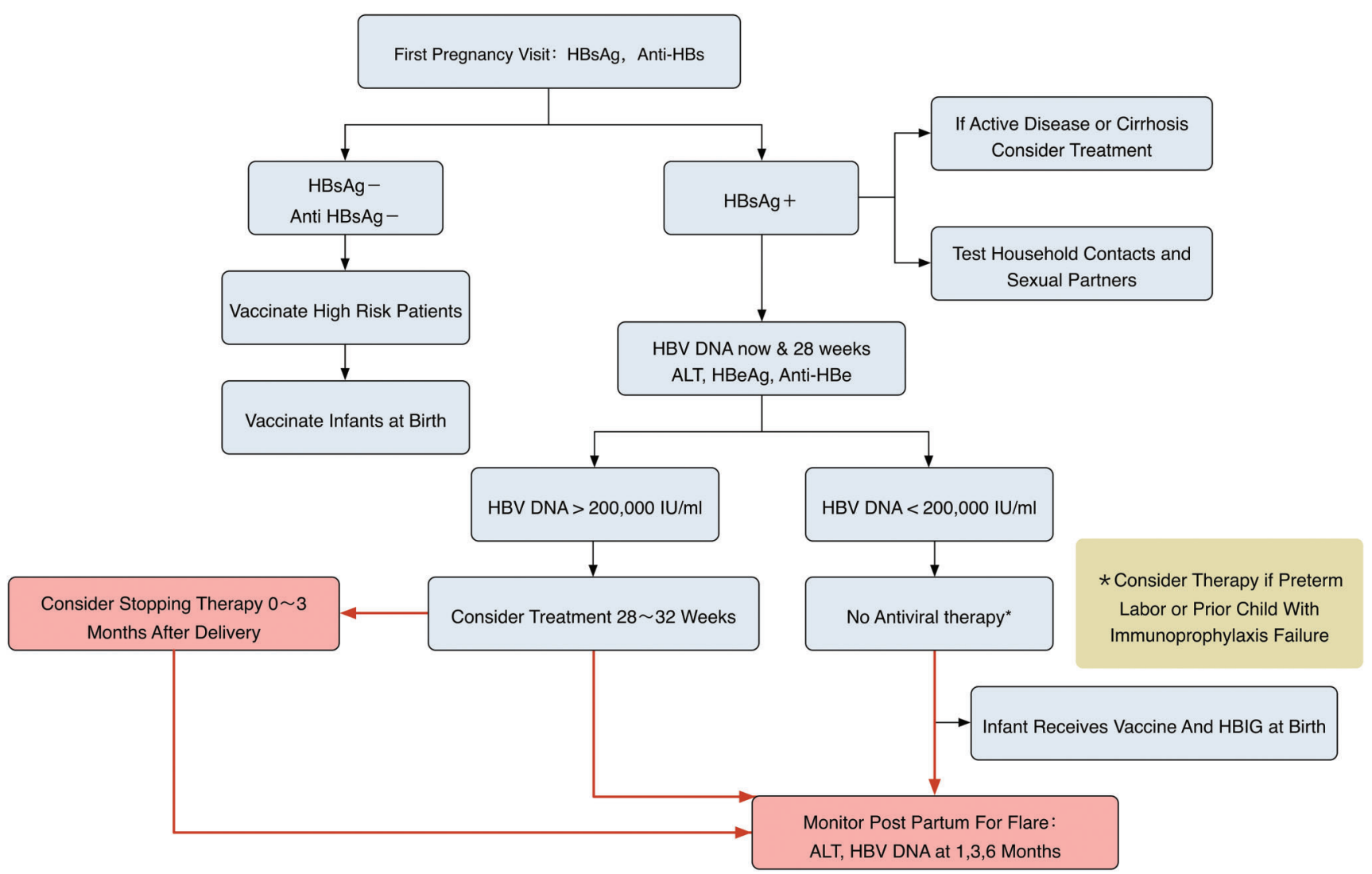

Fig. 1. Suggested management of $\mathbf{H B V}$ in pregnant patients. Adapted from $A A S L D^{5}, A C O G^{28}$ and Pan et al ${ }^{25}$. Abbreviations: Anti-HBSAg, antibody to hepatitis $B$ surface antigen; ALT, alanine aminotransferase; DNA, deoxyribonucleic acid; HBIG, hepatitis B immunoglobulin; HBsAg, hepatitis B surface antigen.

Table 2. Treatment options for chronic HBV in pregnancy 5

\begin{tabular}{|c|c|c|c|c|}
\hline Drug and dose & Indication & $\begin{array}{l}\text { Pregnancy } \\
\text { category }\end{array}$ & Potential side effects & $\begin{array}{l}\text { Risk of } \\
\text { resistance }\end{array}$ \\
\hline $\begin{array}{l}\text { Peg-IFN 2a } 180 \mu \mathrm{g} / \text { week } \\
\text { (Finite therapy may be } \\
\text { used prior to conception) }\end{array}$ & $\begin{array}{l}\text { HBV (HBeAg-positive or - } \\
\text { negative), compensated disease, } \\
\text { viral replication, liver } \\
\text { inflammation }\end{array}$ & $\mathrm{C} \ddagger$ & $\begin{array}{l}\text { Flu-like symptoms, fatigue, } \\
\text { depression, cytopenias, } \\
\text { autoimmune disorders }\end{array}$ & Low \\
\hline Lamivudine $100 \mathrm{mg} / \mathrm{d}$ & $\begin{array}{l}\text { Chronic HBV with viral replication } \\
\text { and liver inflammation }\end{array}$ & $\mathrm{C} \ddagger$ & Pancreatitis, lactic acidosis & High \\
\hline Telbivudine $600 \mathrm{mg} / \mathrm{d}$ & $\begin{array}{l}\text { Chronic HBV with viral replication, } \\
\text { transaminitis, or active histology }\end{array}$ & $\mathrm{B} * *$ & $\begin{array}{l}\text { Myopathy, creatinine kinase } \\
\text { elevation, lactic acidosis }\end{array}$ & Moderate \\
\hline Entecavir $0.5-1 \mathrm{mg} / \mathrm{d}$ & $\begin{array}{l}\text { Chronic HBV with active viral } \\
\text { replication }\end{array}$ & $\mathrm{C} \ddagger$ & Lactic acidosis & $\begin{array}{l}\text { Low in } \\
\text { HBV naïve } \\
\text { patients }\end{array}$ \\
\hline Adefovir $10 \mathrm{mg} / \mathrm{d}$ & Chronic HBV & $\mathrm{C} \ddagger$ & $\begin{array}{l}\text { Acute renal failure, Fanconi } \\
\text { syndrome, nephrogenic } \\
\text { diabetes insipidus, lactic } \\
\text { acidosis }\end{array}$ & Moderate \\
\hline Tenofovir 300 mg/d & Chronic HBV & $\mathrm{B} * *$ & $\begin{array}{l}\text { Nephropathy, Fanconi } \\
\text { syndrome, osteomalacia, } \\
\text { lactic acidosis }\end{array}$ & Low \\
\hline
\end{tabular}

**Animal reproduction studies have shown an adverse effect on the fetus and there are no adequate and well-controlled studies in humans, but potential benefits may warrant use of the drug in pregnant women despite potential risks.

$\ddagger$ Animal reproduction studies have failed to demonstrate a risk to the fetus and there are no adequate and well-controlled studies in pregnant women.

Abbreviations: $\mathrm{HBeAg}$, hepatitis B e antigen; HBV, hepatitis B virus; Peg-IFN 2a, pegylated-interferon 2a. 
The American College of Gastroenterology (ACG) and AASLD guidelines both strongly recommend initiation of antivirals in highly viremic patients at 28-32 weeks of gestation in order to reduce MTCT. Tenofovir and telbivudine remain first-line therapies. A recent prospective trial looked at perinatal transmission rates in highly viremic mothers (HBV DNA $>10^{7}$ log copies $/ \mathrm{mL}$ ) who were administered telbivudine at $600 \mathrm{mg} / \mathrm{d}$ initiated at 20-32 weeks of gestation versus those given no treatment; standard immunoprophylaxis was given to all offspring. There was a significant decrease in the mean viral load of the treatment arm before delivery and no fetal transmission was detected subsequently. However, $8 \%$ of the control group ( 7 of 88 ) transmitted the virus to their infants. The rate of perinatal complications and congenital abnormalities were comparable in each group. ${ }^{33}$ Pan et al ${ }^{34}$ have shown similar efficacy for telbivudine in the prevention of MTCT. Similarly, a Taiwanese group reported that treatment with tenofovir in highly viremic mothers improved maternal ALT levels, decreased infant HBV DNA at birth and decreased infant HBsAg positivity at 6 months. ${ }^{35}$

Han et $a l^{36}$ evaluated lamivudine initiation in the second or third trimester for mothers with high viremia and HBeAg positivity. Similar to findings in telbivudine-treated mothers, the lamivudine-treated mothers had a high rate of response $(160 / 164)$, and higher ALT normalization rate $(90.2 \%$ vs. $55.88 \%)$. By $7-12$ months after birth, none of the infants born to the lamivudine-treated mothers tested positive for HBsAg, compared to $8.7 \%(8 / 92)$ of infants born to mothers in the control group. None of the treated mothers required treatment discontinuation due to resistance or adverse events. ${ }^{36}$ Generally, resistance development is quite rare in short-term therapy. ${ }^{37}$ However, Ayres et a/ ${ }^{38}$ did demonstrate increased resistance to lamivudine even in a short course of therapy. Lamivudine is generally recommended in the third trimester, to avoid resistance development as well as to minimize fetal exposure. If resistance to lamivudine develops, the therapy regimen can be safely switched to tenofovir.

Current recommendations by the AASLD cite HBV DNA levels $>2 \times 10^{5} \mathrm{IU} / \mathrm{mL}$ as an indication for initiation of therapy, as risk of HBV transmission increases with level of viremia. ${ }^{5}$ Pan et $a l^{25}$ have suggested additional parameters for initiation of antiviral therapy, including prolonged uterine contractions or threatened preterm labor, as these may disrupt placental function or cause leakage and increase the risk of MTCT. Additionally, the authors maintain that MTCT risk increases for cases in which a prior child failed immunoprophylaxis and that therapy should be initiated in the proceeding pregnancy. ${ }^{25}$ This has not been adapted into the Hepatology or Obstetrics guidelines to date, as additional studies are needed to confirm these recommendations.

The duration of treatment post-partum varies between $0-3$ months, depending on the indication for treatment initiation, HBsAg positivity, and breastfeeding. ${ }^{11,39}$ Discontinuation of therapy at any point during or after pregnancy requires monitoring because of the potential for HBV flare upon withdrawal of antiviral therapy in the subsequent 6 months.

\section{Mode of delivery: does it matter?}

There is conflicting evidence surrounding the effect of the mode of delivery on the risk of MTCT. Older studies evaluating MTCT rate in infants born via Caesarean section versus vaginal delivery did not show a significant difference in rates of infant HBV infection. ${ }^{40,41} \mathrm{~A}$ more recent meta-analysis revealed a $17.5 \%$ absolute risk reduction with Caesarean section compared to immunoprophylaxis alone, suggesting a benefit of elective Caesarean section to reduce MTCT. ${ }^{42}$ Lee et $a l^{41}$ investigated 1409 infants over a four-year period who had received appropriate immunoprophylaxis at birth and who had been born to HBsAg-positive mothers. They reported MTCT rates of $1.4 \%$ with elective Caesarean section compared to $3.4 \%$ with vaginal delivery and $4.2 \%$ with urgent Caesarean section. Although after stratification according to level of viremia (low vs. high, with a cut-off of 1 million copies $/ \mathrm{mL}$ ), the delivery modality was found to have no impact on MTCT. ${ }^{4}$

To date, there has yet to be a study comparing elective Caesarean section and immunoprophylaxis versus immunoprophylaxis and vaginal delivery in reducing MTCT while assessing for fetal outcomes. While the current guidelines do not recommend a particular mode of delivery, additional validation studies are needed to make an evidence-based recommendation. The Society for Maternal Fetal Medicine states that Caesarean section should not be performed for the sole indication of reducing vertical HBV transmission. ${ }^{43}$

\section{Breastfeeding}

HBsAg, HBeAg and HBV DNA are excreted in breast milk of infected mothers. According to the current World Health Organization there is no additional risk of HBV transmission through breastfeeding, even in the absence of immunization. ${ }^{44}$ However, breastfeeding should be avoided in the presence of cracked or bleeding nipples as this would cause mixing of serous exudates with breast milk and can potentially lead to transmission of hepatitis $B$. There is limited data regarding the safety of breastfeeding while on antivirals. Oral nucleos(t)ide analogs are known to be excreted in low levels in breast milk. ${ }^{45}$ While the AASLD and ACOG recommendations support breastfeeding on antivirals, additional research regarding the potential excretion of these medications through breast milk and its effects on infants are needed before definitive recommendations can be made.

\section{Conclusions}

The management and treatment of chronic hepatitis $B$ is difficult owing to its variable disease course. It is even more complex in the pregnant patient. Shared decision-making between the physician and the female patient regarding timing of initiation of antiviral therapy is vital to improving outcomes. Optimal initiation of antiviral therapy in the general population depends on the degree of histological inflammation and fibrosis. This holds true for pregnant women as well. We now know that post-partum HBIG and vaccination for infants born to mothers who are chronically infected can be ineffective in preventing MTCT in the setting of elevated maternal level of HBV viremia.

Treatment is generally not indicated in those wishing to become pregnant, as this age group tends to be in the immune-tolerant phase. Females with HBV DNA > 200,000 $\mathrm{IU} / \mathrm{mL}$ should have a discussion about starting therapy in the third trimester. Women in the immune-active phase or with advanced stages of liver disease should be on therapy throughout their pregnancy to avoid serious morbidity or mortality of both the mother and fetus. Some experts suggest that women in preterm labor or women who had a previous child who had failed passive-active immunoprophylaxis should also receive therapy regardless of the HBV viral 
load. Avoidance of therapy in the early stages of pregnancy is recommended to avoid unnecessary exposure to the fetus during early development, although additional studies are needed to evaluate antiviral therapy on organogenesis. First-line therapies include tenofovir or telbivudine. If a patient does not wish to initiate therapy, she should still be monitored carefully for flares throughout her pregnancy. Based on the current AASLD and ACOG guidelines, there is no preferred mode of delivery to prevent fetal transmission of the virus. Breastfeeding is recommended for infant health.

\section{Conflict of interest}

Dr. Walid S Ayoub has served as consultant for Gilead, BMS, and Abbvie. Dr. Erica Cohen has no interests related to this study.

\section{Author contributions}

Provided the conception and design of the study, collection and analysis of the data and drafting of the article (WSA, EC).

\section{References}

[1] Management of hepatitis B and HIV coinfection. Available from: http://www. euro.who.int/_data/assets/pdf_file/0011/152012/e95792.pdf.

[2] Grossblatt N. Hepatitis and Liver Cancer: National Strategy for Prevention and Control of Hepatitis B and C. Institute of Medicine (US) Committee on the Prevention and Control of Viral Hepatitis Infections. Washington, DC: National Academies Press, 2010.

[3] Wasley A, Kruszon-Moran D, Kuhnert W, Simard EP, Finelli L, McQuillan G, et al. The prevalence of hepatitis $B$ virus infection in the United States in the era of vaccination. J Infect Dis 2010;202:192-201. doi: 10.1086/653622.

[4] Kowdley KV, Wang CC, Welch S, Roberts H, Brosgart CL. Prevalence of chronic hepatitis $\mathrm{B}$ among foreign-born persons living in the United States by country of origin. Hepatology 2012;56:422-433. doi: 10.1002/hep.24804.

[5] Terrault NA, Bzowej NH, Chang KM, Hwang JP, Jonas MM, Murad MH, et al. AASLD guidelines for treatment of chronic hepatitis B. Hepatology $2016 ; 63$ : 261-283. doi: 10.1002/hep.28156.

[6] Tran TT. Hepatitis B in Pregnancy. Clin Infect Dis 2016;62 Suppl 4: S314-S317. doi: 10.1093/cid/ciw092.

[7] Gish RG, Gadano AC. Chronic hepatitis B: current epidemiology in the Americas and implications for management. J Viral Hepat 2006;13:787-798. doi: 10.1111/j.1365-2893.2006.00787.x.

[8] Smith EA, Jacques-Carroll L, Walker TY, Sirotkin B, Murphy TV. The national perinatal hepatitis B prevention program, 1994-2008. Pediatrics 2012;129: 609-616. doi: 10.1542/peds.2011-2866.

[9] Singh AE, Plitt SS, Osiowy C, Surynicz K, Kouadjo E, Preiksaitis J, et al. Factors associated with vaccine failure and vertical transmission of hepatitis B among a cohort of Canadian mothers and infants. J Viral Hepat 2011;18: 468-473. doi: 10.1111/j.1365-2893.2010.01333.x.

[10] Burk RD, Hwang LY, Ho GY, Shafritz DA, Beasley RP. Outcome of perinatal hepatitis B virus exposure is dependent on maternal virus load. J Infect Dis 1994;170:1418-1423. doi: 10.1093/infdis/170.6.1418.

[11] European Association for the Study of the Liver. EASL clinical practice guidelines: Management of chronic hepatitis B virus infection. J Hepatol 2012;57:167-185. doi: 10.1016/j.jhep.2012.02.010.

[12] Alter MJ. Epidemiology of hepatitis B in Europe and worldwide. J Hepatol 2003;39:S64-S69. doi: 10.1016/S0168-8278(03)00141-7.

[13] Publicover J, Gaggar A, Nishimura S, Van Horn CM, Goodsell A, Muench MO, et al. Age-dependent hepatic lymphoid organization directs successful immunity to hepatitis B. J Clin Invest 2013;123:3728-3739. doi: 10.1172/JCI68182.

[14] Carey I, D'Antiga L, Bansal S, Longhi MS, Ma Y, Mesa IR, et al. Immune and viral profile from tolerance to hepatitis $B$ surface antigen clearance: a longitudinal study of vertically hepatitis B virus-infected children on combined therapy. J Virol 2011;85:2416-2428. doi: 10.1128/JVI.01449-10.

[15] Lin HH, Lee TY, Chen DS, Sung JL, Ohto H, Etoh T, et al. Transplacental leakage of $\mathrm{HBeAg}$-positive maternal blood as the most likely route in causing intrauterine infection with hepatitis B virus. J Pediatr 1987;111: $877-881$.

[16] Lazizi Y, Badur S, Perk Y, Ilter O, Pillot J. Selective unresponsiveness to HBsAg vaccine in newborns related with an in utero passage of hepatitis $B$ virus DNA. Vaccine 1997;15:1095-1100.
[17] Kim GA, Lee HC, Kim MJ, Ha Y, Park EJ, An J, et al. Incidence of hepatocellular carcinoma after $\mathrm{HBsAg}$ seroclearance in chronic hepatitis $B$ patients: a need for surveillance. J Hepatol 2015;62:1092-1099. doi: 10.1016/j.jhep.2014. 11.031.

[18] Cohen E, Tran TT. Hepatitis B in the female population. Gastroenterol Clin North Am 2016;45:359-370. doi: 10.1016/j.gtc.2016.02.011.

[19] Fontana RJ. Side effects of long-term oral antiviral therapy for hepatitis B. Hepatology 2009;49:S185-S195. doi: 10.1002/hep.22885.

[20] Chu CM, Lin CC, Chen YC, Jeng WJ, Lin SM, Liaw YF. Basal core promoter mutation is associated with progression to cirrhosis rather than hepatocellular carcinoma in chronic hepatitis B virus infection. Br J Cancer 2012;107:20102015. doi: 10.1038/bjc.2012.474.

[21] Brunetto MR, Oliveri F, Colombatto P, Moriconi F, Ciccorossi P, Coco B, et al. Hepatitis $B$ surface antigen serum levels help to distinguish active from inactive hepatitis B virus genotype D carriers. Gastroenterology 2010;139: 483-490. doi: 10.1053/j.gastro.2010.04.052.

[22] Lau GK, Piratvisuth T, Luo KX, Marcellin P, Thongsawat S, Cooksley G, et al. Peginterferon Alfa-2a, lamivudine, and the combination for $\mathrm{HBeAg}$-positive chronic hepatitis B. N Engl J Med 2005;352:2682-2695. doi: 10.1056/ NEJMoa043470.

[23] Shaheen AA, Myers RP. The outcomes of pregnancy in patients with cirrhosis: a population-based study. Liver Int 2010;30:275-283. doi: $10.1111 / \mathrm{j} .1478$ 3231.2009.02153.x.

[24] Kim HY, Choi JY, Park CH, Jang JW, Kim CW, Bae SH, et al. Outcome after discontinuing antiviral agents during pregnancy in women infected with hepatitis B virus. J Clin Virol 2013;56:299-305. doi: 10.1016/j.jcv.2012.11.019.

[25] Pan CQ, Duan ZP, Bhamidimarri KR, Zou HB, Liang XF, Li J, et al. An algorithm for risk assessment and intervention of mother to child transmission of hepatitis B virus. Clin Gastroenterol Hepatol 2012;10:452-459. doi: 10.1016/j. cgh.2011.10.041

[26] Tse KY, Ho LF, Lao T. The impact of maternal HBsAg carrier status on pregnancy outcomes: a case-control study. J Hepatol 2005;43:771-775. doi: 10. 1016/j.jhep.2005.05.023.

[27] Lao TT, Chan BC, Leung WC, Ho LF, Tse KY. Maternal hepatitis B infection and gestational diabetes mellitus. J Hepatol 2007;47:46-50. doi: 10.1016/j. jhep.2007.02.014.

[28] American College of Obstetricians and Gynecologists. ACOG Practice Bulletin No. 86: Viral hepatitis in pregnancy. Obstet Gynecol 2007;110:941-956. doi: 10.1097/01.AOG.0000263930.28382.2a.

[29] Nguyen G, Garcia RT, Nguyen N, Trinh H, Keeffe EB, Nguyen MH. Clinical course of hepatitis $B$ virus infection during pregnancy. Aliment Pharmacol Ther 2009;29:755-764. doi: 10.1111/j.1365-2036.2009.03932.x.

[30] Zou H, Chen Y, Duan Z, Zhang H, Pan C. Virologic factors associated with failure to passive-active immunoprophylaxis in infants born to $\mathrm{HBsAg}$ positive mothers. J Viral Hepat 2012;19:e18-e25. doi: 10.1111/j.13652893.2011.01492.x.

[31] Bai H, Zhang L, Ma L, Dou XG, Feng GH, Zhao GZ. Relationship of hepatitis B virus infection of placental barrier and hepatitis $B$ virus intra-uterine transmission mechanism. World J Gastroenterol 2007;13:3625-3630.

[32] Kar P, Mishra S. Management of hepatitis B during pregnancy. Expert Opin Pharmacother 2016;17:301-310. doi: 10.1517/14656566.2016.1118051.

[33] Han GR, Cao MK, Zhao W, Jiang HX, Wang CM, Bai SF, et al. A prospective and open-label study for the efficacy and safety of telbivudine in pregnancy for the prevention of perinatal transmission of hepatitis B virus infection. J Hepatol 2011;55:1215-1221. doi: 10.1016/j.jhep.2011.02.032.

[34] Pan CQ, Han GR, Jiang HX, Zhao W, Cao MK, Wang CM, et al. Telbivudine prevents vertical transmission from $\mathrm{HBeAg}$-positive women with chronic hepatitis B. Clin Gastroenterol Hepatol 2012;10:520-526. doi: 10.1016/j. cgh.2012.01.019.

[35] Chen HL, Lee CN, Chang CH, Ni YH, Shyu MK, Chen SM, et al. Efficacy of maternal tenofovir disoproxil fumarate in interrupting mother-to-infant transmission of hepatitis B virus. Hepatology 2015;62:375-386. doi: 10. 1002/hep. 27837

[36] Han GR, Jiang HX, Zhao W, Ge CY, Xu CL, Pan C. Lamivudine use in the 2nd or 3rd trimster of pregnancy has similar effecacy in preventing vertical transmission (VT) of chronic hepatitis $B(\mathrm{CHB})$ in highly viremic mothers. Hepatology 2011;54:479A.

[37] Xu WM, Cui YT, Wang L, Yang H, Liang ZQ, Li XM, et al. Lamivudine in late pregnancy to prevent perinatal transmission of hepatitis $B$ virus infection: $a$ multicentre, randomized, double-blind, placebo-controlled study. J Viral Hepat 2009;16:94-103. doi: 10.1111/j.1365-2893.2008.01056.x.

[38] Ayres A, Yuen L, Jackson KM, Manoharan S, Glass A, Maley M, et al. Short duration of lamivudine for the prevention of hepatitis $B$ virus transmission in pregnancy: lack of potency and selection of resistance mutations. J Viral Hepat 2014;21:809-817. doi: 10.1111/jvh.12212.

[39] Whittaker G, Herrera JL. Hepatitis B in Pregnancy. South Med J 2014;107: 195-200. doi: 10.1097/SMJ.0000000000000077.

[40] Lamberth JR, Reddy SC, Pan J], Dasher KJ. Chronic hepatitis B infection in pregnancy. World J Hepatol 2015;7:1233-1237. doi: 10.4254/wjh.v7.i9. 1233. 
Ayoub W.S. et al: Hepatitis management in the pregnant patient

[41] Lee SD, Lo KJ, Tsai YT, Wu JC, Wu TC, Yang ZL, et al. Role of caesarean section in prevention of mother-infant transmission of hepatitis $B$ virus. Lancet 1988;2:833-834. doi: 10.1016/S0140-6736(88)92792-4.

[42] Hu Y, Chen J, Wen J, Xu C, Zhang S, Xu B, et al. Effect of elective cesarean section on the risk of mother-to-child transmission of hepatitis $B$ virus. BMC Pregnancy Childbirth 2013;13:119. doi: 10.1186/1471-2393-13-119.

[43] Society for Maternal-Fetal Medicine (SMFM), Dionne-Odom J, Tita AT, Silverman NS. Hepatitis B in pregnancy screening, treatment, and prevention of vertical transmission. Am J Obstet Gynecol 2016;214:6-14. doi: 10.1016/j. ajog.2015.09.100.

[44] Protection against viral hepatitis. Recommendations of the Immunization Practices Advisory Committee (ACIP). MMWR Recomm Rep 1990;39:1-26.

[45] Benaboud S, Pruvost A, Coffie PA, Ekouévi DK, Urien S, Arrivé E, et al. Concentrations of tenofovir and emtricitabine in breast milk of HIV-1-infected women in Abidjan, Cote d'Ivoire, in the ANRS 12109 TEmAA Study, Step 2. Antimicrob Agents Chemother 2011;55:1315-1317. doi: 10.1128/AAC. 00514-10. 